\title{
VWA5A wt Allele
}

National Cancer Institute

\section{Source}

National Cancer Institute. VWA5A wt Allele. NCI Thesaurus. Code C54304.

Human VWA5A wild-type allele is located within $11 \mathrm{q} 24.2$ and is approximately $32 \mathrm{~kb}$ in leng th. This allele, which encodes von Willebrand factor $A$ domain-containing protein $5 \mathrm{~A}$, is putatively involved in the inhibition of cell cycle progression. Deletion of the VWA5A gene may be associated with several types of cancer such as breast, lung and thyroid carcinomas. 